\title{
Polish highlander jokes and their targets
}

\author{
Wladysław Chłopicki \\ Jagiellonian University \\ w.chlopicki@uj.edu.pl
}

\author{
Dorota Brzozowska \\ Opole University \\ dbrzozowska@uni.opole.pl
}

\begin{abstract}
The aim of the paper is to identify the characteristic features of jokes about Polish highlanders and analyse them to isolate the comic script of a highlander. This group of jokes is treated as a good illustration of Christie Davies's ethnic jokes theory concerning canny versus stupid and centre versus periphery oppositions, as well as mind over matter. A particular type of reasoning and the use of regional dialect are distinctive features of the joke targets that make it possible to perceive these jokes as a culturally specific phenomenon. The head shepherd (called baca) is the key character of the cycle. He is a very down-to-earth person, who is proud of his practical wisdom and has a very relaxed attitude to life-a wise fool in some jokes, thus even resembling Good Soldier Švejk in some respects. His lifestyle is usually contrasted with that of ceper-a town dweller, coming to the highlands as a touristtreated as a kind of intruder who asks stupid questions and does not know how to appreciate life and what really matters in it. The jokes about highlanders are analysed within the paradigm of General Theory of Verbal Humour, and particularly its reasoning and reversal Logical Mechanisms. Even though Christie Davies treated the Logical Mechanism with some scepticism, claiming it is of no use in the GTVH (Davies 2004, 2011b), he would not probably mind the logic of highlanders' utterances and behaviour being analysed. We believe he may even have enjoyed that.
\end{abstract}

Keywords: highlander, Polish, logical mechanisms, comic script, cleverness, stupidity, wise fool.

The initial stimulus for the topic of the present article for the special commemorative issue devoted to the scholarship of late Christie Davies was the discussion on the subject that took place in the year 2000 at Kamien Śląski in southern Poland, following the international conference on Humour and Laughter organized there by Dorota Brzozowska. Then, in a remote mountain cottage of southern Poland, Christie Davies and Władysław Chłopicki debated highlander jokes, with Salvatore Attardo as active witness to the discussion, the 
warm fireplace of the cottage making the place cosy, the rain pouring steadily outside. The bone of contention was the degree of cleverness of the highlander in the jokes. Davies argued that from a broad, historical comparative perspective on stupidity jokes of this kind it was the highlander that was the butt of the joke, being stupid and backward, living in a remote, rural location - the "cultural periphery", unaware of the progress modern civilization has made, while the tourist was the representative of the cultural centre, of urban background, modern and progressive. In contrast, Chłopicki argued that from his perspective the highlander in Polish jokes was an old wise man, in touch with cultural grassroots, his clever philosophy reminding the urban folk who come to the mountains as tourists and find it difficult to adjust to the slow rural way of life that the modern civilization has removed itself unnecessarily from the basic, common-sensical approach to life and thus loses out when faced with adversity. Davies was right from his broader, global perspective, of course, but Chłopicki had his point too, from his local perspective. This paper explores the very opposition of the generic versus culture-specific, attempting to shed light on the latter in the context of the former.

\section{The Tatra Highlands as a source of inspiration for Polish intellectuals}

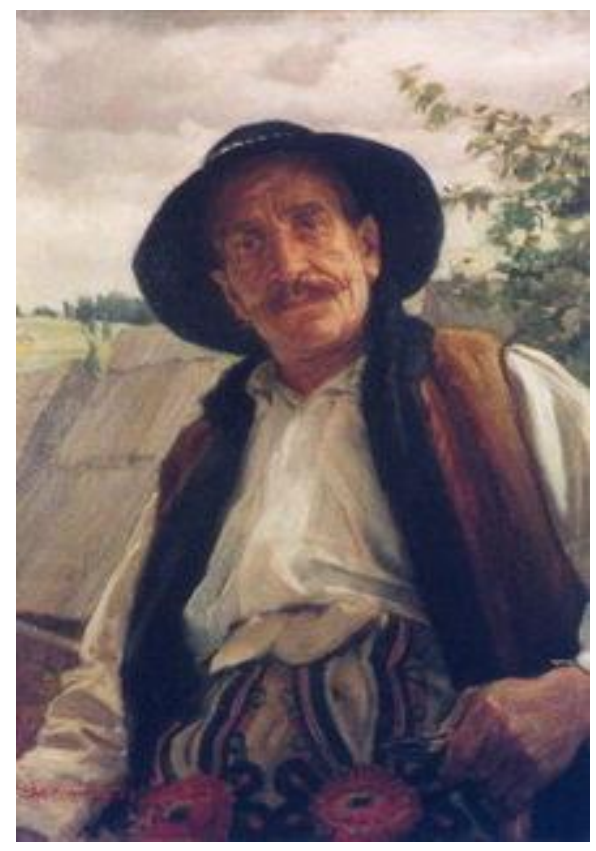

Figure 1. A baca as envisioned by Bolesław Barbacki (1933).

(https://pl.wikipedia.org/wiki/Baca)

The Podhale foothills is the area of southern Poland flanking the Tatra Mountains from the north, which used to be much isolated from the rest of the country due to its remote location. Until the late 19th century, this area suffered dire poverty as the land of severe weather, isolated by surrounding mountain chains and deprived of easy access. The main source of income of its inhabitants was farming and raising flocks of sheep. Still the area proudly emphasized its rich folklore tradition, the more so because starting from the late 19th century it was "discovered" by urban folk from Kraków and from Warsaw, who started coming over to take advantage of the healthy climate to spend their holidays there, at the same time mixing with local highlanders. It should be pointed out that this was the period in Polish culture when urban intellectuals started to be fascinated by the "purely national" culture of 
rural areas. ${ }^{1}$ The root cause of their fascination was the broad conviction that the rural culture with its colourful, robust folklore and historical dialects actually preserved the "essence of Polishness", then endangered by Germanising or Russifying efforts of the foreign powers occupying Poland in the 19th century.

The region also yielded one of the greatest Polish philosophers of late 20th century, Rev. Józef Tischner, who originated from the Podhale foothills (he was born there in 1931) and never forsook his highlander origin, even when he became a professor of Papal Academy of Theology in Kraków. He made a name for himself as a preacher in the Kraków university church of St Ann's; he was highly popular among Jagiellonian University students as a lecturer on philosophy in the early 1980s, at the time when a fresh, non-communist perspective was highly valued at the university. ${ }^{2}$ One of the reasons of his popularity was the straightforward, robust language and colourful examples and metaphors he used to explain the most complicated philosophical ideas of such abstruse philosophers as Kant, Heidegger, Levinas or Husserl. Among his numerous publications, one became a true bestsellerFilozofia po góralsku [A History of Philosophy the Highlander Way], advertised by the publisher with the saying of Tischner's: If you cannot translate something into the highlander speech, it is not true (http://www.katolik.pl/jegomosc-tischner-nas-podhalanskimedrol,1482,416,cz.html?s=2). The book written in a tongue-in-cheek manner perhaps had a serious message: highlander culture should be appreciated for its robustness and profundity, not least through the special dialect it uses (the book is written in heavy dialect too). Gotówka (2016) thus comments on his attitude to the Highlands:

Rev. Józef Tischner was an excellent observer who was able to notice things that the Highlanders wanted to hide on the one hand, and, on the other hand, things that they were proud of. He gave the following answer to the question: "What are the people of mountains like in fact?..."They have all the faults of other people, and maybe even more. But they also have some advantages, which the other people have not got. In extremely tough times, in the 18th and 19th centuries, they were able to create an individual synthesis of cultures, including the elements of different origins in the folk culture, in which they express themselves up until today. The components of this culture are as follows: language, music, dance, a very characteristic type of piety, a strong experience of freedom, an attitude provoking danger".

(Tischner 2003b: 22)

Tischner was a preacher thus the moral message of his philosophy and the emphasising of the "natural" faith of the highlanders cannot be underestimated.

Undoubtedly, Tischner's objective was also to popularise philosophy among the reading public, and humour combined with the highlander dialect, much loved by the Poles for its aptness and no-nonsense nature, seemed an ideal way to achieve his aim. In his book Tischner represented some of the fellow highlanders he had known as philosophers, because in their synthetic thinking they touched upon issues central to mainstream philosophy. Some extracts of the book are highly telling:

O tym jak Jedruś Kudasik, nas podhalański Socrates naucyt ludzi, co worce a co nie worce wiedzieć [On how Jędruś (dim. for Andrew) Kudasik, our Highland Socrates, taught people what is worth and what is not worth knowing]

(Tischner 2003a: 55)

O Tadku Pudziszu z Gronkowa, piyrsym na świecie Arystotelesie, jako ludziom thumacul, co mojom robić, kied fcom poznać [On Tadek Pudzisz from Gronków, the first Aristotle in the world, how his explained to people what they are to do if they want to know things]

(Tischner 2003a: 130) 
(po nocy w górach i dużej porcji okowity)...niedaleko Tylkowyk Kominów narodziyt się tyn, co go Grecy Platonem nazwali, a po prawdzie byt to Władek Trebunia-Tutka z Białego Dunajca. Jemu się wse widziato, ze sytko, nie pomijajacy jego samego, jest cieniem samego siebie. [(Following a night out in the mountains and a great deal of moonshine), near Mt Kominy Tylkowe, he whom the Greeks called Plato was born, but in fact this was Władek Trebunia-Tutka from Biały Dunajec. It seemed to him that everything, including himself, was a shadow of itself].

(Tischner 2003a :77)

Rak (2015) identifies 34 "culturemes" (or cultural themes) which in his view are essential to understand the culture of the Podhale foothills. They include a number of special categories situated on the domestic and alien scale (the baca and robber being among the domestic, and the ceper - the urban visitor - among the alien ones), as well as more generally positive values (God, Jesus, the Virgin Mary Lady of Podhale, the cross, freedom, honour, work, and money) and negative ones (poverty and hunger).

\section{The figure of a highlander in jokes}

The specific figure of the highlander emerges from the unique cultural context of Polish Podhale foothills. Due to the region's poverty, highlanders grew to be thrifty, pretty much like the $S \operatorname{cots}^{3}$, and again like the Scots many of them were forced to emigrate to America. While over there, they found it difficult to blend in, as they had different hygienic habits ${ }^{4}$ and they did not know the language. Thus, they became the subject of jokes such as the one below, where they were portrayed as clever in their own way, or rather not quite so.

1.Przyjechat baca do Ameryki i okradt bank. Siada w rowie przydrożnym, wyciaga $z$ worka pieniądze I zaczyna liczyć. Nagle zjawia się przy nim amerykański funkcjonariusz i pokazuje stużbowa oznakę z napisem „Police”. Na to baca:

- Dziękuje panoczku, sam se police.

(Pinkwart, Pytlik 2009: 99)

[A baca arrived in America and robbed a bank. He sat in a road-side ditch, took the money out of the bag and started counting. Suddenly an American officer turns up next to him and shows him his badge with "Police" written on it. Upon this the baca says:

"Thank you, mister. I will count myself [Pol. police]. $]^{5}$

The term panoczku (vocative, nominative panoczek), which the highlander uses to address the non-highlander, is of interest here. It derives from pan (mister, sir, originally landlord), and grammatically is a diminutive, thus expressing a certain degree of affective condescension that the highlander feels towards others. The term is commonly used while addressing any tourist or visitor, who is also referred to in the third person as ceper - there the affectivity identifiable in panoczek seem absent.

A related classical one-liner describes the impromptu cleverness of the highlanders:

2.Trzeba sobie jakoś radzić, powiedział baca, zawiazując buta dżdżownica. (http://irek-wojciech.republika.pl/humor/temat/obacy1.htm, 17 September 2017)

[One should make do somehow, said a baca tying his shoe with an earthworm.]

The one-liner is so well known that nowadays it is often used metaphorically in circumstances when a problem is solved in a haphazard way, such as in the meme below (these are locally known as "demotivators" due to their ironic self-deprecation; http://demotywatory.pl/1847103/Trzeba-sobie-jakos-radzic). 


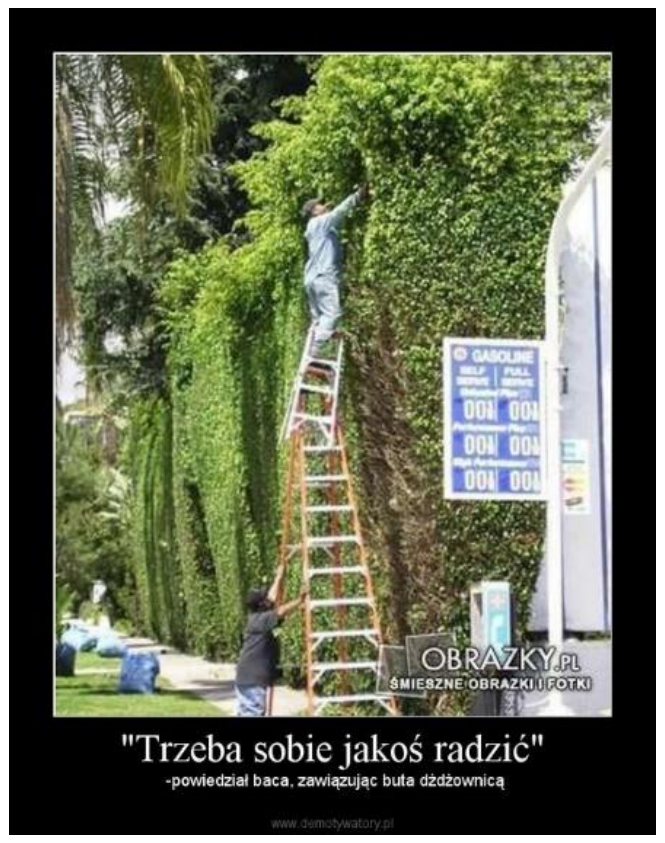

Figure 2. One should make do somehow, said a baca, tying his shoe with an earthworm

As Davies used to write and say, comic scripts are fictitious, but they emerge not without a social or historical reason (Davies 1990). The figure of a baca-admittedly somewhat selfcontradictory - that emerges from the analysis of jokes performed for the present paper is the following: a strong, but lazy, promiscuous and sometimes dirty drunkard who likes to get things done his way without much effort, uses his vernacular language and perceives the world in an essentialist, often misleading, although doubtless creative way. This makes him a good example of the wise old man (also called senex, sage or Sophos) figure - typically seen as archetypical as described by Carl Jung or as classic literary figure, who can be a profound philosopher distinguished for sound judgment and is usually a stranger (the use of dialect will mark this feature). In the remaining part of the article the features which contribute to the image are discussed on the basis of relevant examples that we have selected from the collections of Polish highlander jokes as well as Internet sources (all listed in the references section). ${ }^{6}$

First of all, the baca is lazy - or we may say that he saves his energy, he could so often be seen in a still pose, characteristic of those who practise meditation - and does not feel like working. He does little, and usually keeps calm, unless despairing like in 3.

3.Idzie turysta po szlaku i nagle styszy:

- Ło Jezuuuu!!! Jezu, Jezu, Jezu, Jezusicku!!!!

Biegnie, patrzy a tu baca siedzi na pieńku, obok wbita siekiera $i$ :

- Ło Jezu, Jezu, Jezu!

Turysta: Baco! Baco co wam sie stało?!

Baca: Mnie? Nic. Ło Jezuuuu!!! Jezu, Jezu, Jezu!!!

T: A może komuś w waszej rodzinie?

B: Mojej? Ni. Ło Jezu, Jezu, Jezu, Jezusicku!!!

T: No to co tak lamentujecie?

B: Ło Jezu, jak mi się robić nie chce!

(http://www.dowcipy.jeja.pl/130,idzie-turysta-po-szlaku-i-nagle.html, 17 September 2017)

[A tourist walks along a trail and suddenly hears: "Oh, Jeesus, Jeesus!"

He runs towards the sound and sees a baca sitting on a tree stump with an axe driven into the ground next to it and: 
"Oh Jeesus, sweet Jeesus".

Tourist: "Baca! What happened to you?"

Baca: "To me? Nothing. Oh Jeesus! Jesus!

"Maybe to someone from your family?

"Mine? No. Oh Jeesus, Jesus.

"So why are you moaning so much?

“'Oh, Jeesus, I don't feel like working so muuuch!”]

Here a clear parallel can be drawn, e.g., to the figure of a Montenegrin in jokes (cf.

Koncewicz-Dziduch 2017) who as a highlander (Montenegro is a mountainous country) is depicted as lazy too, as in this short example:

4. Where does a Montenegrin's wife hide money? Under the shovel.

(Koncewicz-Dziduch 2017: 76)

5. Baco, co robicie, jak macie wolny czas?

- Siedzem i dumiem...

- A jak nie macie czasu?

- To ino siedzem...

(http://dowcipy999.pl/dowcipy/baca_i_wolny_czas, 17 September 2017)

["Baca, what do you do when you have free time?"

"I sit and think."

"And what if you don't?"

"Then I just sit."]

In 5 an image of a baca as a philosopher emerges, which brings to mind another famous, although no doubt tongue-in-cheek saying of Tischner's, expressed in highlander speak, which draws on his conviction that highlanders are genuinely profound in their thinking:

Ale Grecy to nie byli Grecy, ino górole, co udawali greka. Bo na pocątku nie byto Greków, ino wsędy byli górole

[But Greeks were not Greeks, only the highlanders who played dumb (lit. pretended to be Greek). Because in the beginning there were not any Greeks, only highlanders were everywhere]

(Tischner 2003a: 5)

6 uses the image of a local product, oscypek (goat cheese), which when produced in the traditional way smells of smoke and burnt wood.

6. Bacę zaproszono w karnawale na bal przebierańców. Znajomi pytaja go za co się przebierze?

- A za toscypka.

- A jak to baco, za oscypka?

- A siądę se w kąciku i będę śmierdziat.

(http://www.dowcipy.jeja.pl/nowe,3,baca.html, 10 September 2017)

[During the carnival, a baca was invited to a fancy dress party. His acquaintances ask him what costume he will wear.

"A goat cheese costume"

"What do you mean a goat cheese costume, Baca?"

"I will sit quietly in a corner and I will stink"]

The highlander is naturally fond of drinking alcohol, and many jokes describe him when drinking, but not all the jokes (like 7) hinge on that habit; some consider the activity as a standard part of the setup (cf. 8).

7. W karczmie pije dwóch górali. 
- Franuś, cego Ty ocy zamykos przy piciu gorzołecki? Pyta Stasiek.

- Bom przyrzekt babie, że się na wódkę nie popatrze

(HsG: 4)

[Two highlanders in an inn sit and drink.

"Franuś, why d'ya close yr'eyes when ya drink booze?" Stasiek asks.

"'cause I promised my woman that I'll not look at alcohol"]

8. Dwóch górali pije w karczmie:

- Ty tu siedzis ze mna i gorzałkę pijes, a pany ci babe obracaja na deskach, że aż trzescy.

- Ghupiś Józek, jo desek ni mom.

(SHsG: 22)

[Two highlanders sit and drink in an inn:

"You're sittin' here with me and boozin', and the landlords are turning yr woman around on the pile of planks there, so that it all creaks."

"You're stupid, Józek. I have no planks"]

The figure of the highlander depends for its completeness on the sense of playful aggression, so central to the argument advanced by Christie Davies. The central image is that of physical force, potentially (9) or actually (10) exerted by the highlander (who is usually portrayed as physically strong); alternatively, the force could be exerted upon him (11).

9. Baco pobiliście sąsiada, czy macie coś na swoja obronę,

Nic, policja mi orczyk zabrała.

(http://www.dowcipy.jeja.pl/nowe,3,baca,9.html, 17 September 2017)

["Baca, you have beaten up your neighbour, do you have anything in your defence?"

"Nothing, the police took my lever from me."]

10.Spotyka się dwóch gazdów.

- Jako zyjes ze swoja babą?

- Jako dwa gołabecki.

- Jak to?

- Raz ja furgom przez okno, a jak ja dobije to ona furgo przez okienecko

[Two highlanders meet up.

(SHsG: 8)

"How do you live with your woman?"

"Like two little pigeons"

"How is that?"

"Sometimes I hurtle thru the wee window, and another time when I knock her she hurtles thru it."]

11. Baco, styszatem, że wczoraj pobili cię w lesie...

- Phi, też mi las, ledwie parę drzew.

(http://adonai.pl/humor/teksty/?id=32, 11 September 2017)

["Baca, I heard you were beaten up in the forest yesterday..."

"Phew, some forest, just a few trees."]

The highlander is certainly interested in women other than his wife, although he treats sex rather technically (12), while he considers his own woman (his baba) a hag (13), and she returns the favour (14).

12. W Tatrach na hali opala się naga blondyna. Raczej śpi, albo jest mocno zamyślona. Przechodzacy turysta zgorszony widokiem nagiego damskiego tona ... przykrywa je swoim kapeluszem...Przychodzi Baca, patrzy i mówi: - O Jezusicku! Wciagnęło faceta.

(http://dowcipy999.pl/dowcipy/baca_i_naga_blondynka, 17 September 2017) 
[On a high meadow in the Tatra mountains, a naked blonde is sun tanning. She is either asleep or deep in thought. A passing tourist is scandalised by the sight of a naked woman's privates and he covers it with a hat. A baca comes by, looks and says: "O Jeesus! A chap got sucked in!"]

13. Wchodzi baca do sklepu i nie zamyka drzwi.

- Baco, drzwi w domu nie macie? - Krzyczy na niego sprzedawczyni.

- Mom, i taka cholere jak wy, tyz mom.

(http://adonai.pl/humor/teksty/?id=32, 17 September 2017)

[Baca comes in the shop and does not close the door behind him.

"Baca, don't you have a door in the house?", the female shop assistant shouts at him.

"Yeah, I do, and I have such a hag like you too."]

14. Baba z Witowa na spowiedzi wyznaje, że rozbila garnek na głowie swego chtopa, bo tak ja wkurzyt za chodzenie do dziewek we wsi.

- A żatujecie swego czynu? - pyta ksiadz.

- Bardzo żatuje, garnek byt pikny, a i drogi!

(HsG: 21)

[A woman from Witów goes to confession and says that she has broken a pot on the head of her man, because he pissed her off so much for going to see the girls in the village.

"Do you regret your sin?" asks the priest.

"Very much, the pot was so pretty and expensive!"]

With regard to the sex domain, the Polish highlander, like those in Wales and Scotland, also tends to be inappropriately fond of sheep. As Davies writes in the section "Men without women, jokes about sheep" of his study entitled Jokes and Targets, "ethnic jokes about man having carnal connection with sheep are told about the Welsh, the Scots, The New Zealanders, the Sardinians, or any other country or US state [...], where sheep farming is important, or in Greece [...] about shepherds generally" (2011a: 166-167). It must be emphasized, however, that jokes such as 15 below are not particularly common in Poland.

15. Tatry. Mgła jak mleko. Przy szlaku siedzi baca z turysta. Ćmia fajeczkę i papierosa:

- Oj baco, baco...

- Loj turysto, turysto...

- Oj lubicie wy owieczki, panie baco, lubicie...

- Łoj, łodwalcie się! Nie trza byto leźć w góry w tym kozuchu, panie turysto...

(http://www.dowcipy.jeja.pl/nowe,3,baca.html, 10 September 2017)

[The Tatras. It is so foggy that the air looks like milk. Baca is sitting next to the trail with a tourist. One smokes a pipe and the other a cigarette.

"Oh, Baca, Baca"

"Oh, you, tourist, tourist"

"Oh, you like your little sheep, Mr Baca, don't you?"

"Oh, fuck off! Who asked to put on that fur coat when you were walking in the mountains, $\mathrm{Mr}$ Tourist?’]

In contrast, here are some typical Welsh jokes on the subject:

16. Q: What do you call a sheep tied to a fence in Wales?

A: A leisure centre.

17. Q. What do you call a Welshman with many girlfriends?

A. A Shepherd.

(http://www.celticcountries.com/humour/28-jokes-about-the-welsh, 11 September 2017)

18. The Welsh farmer's wife gave him a plate of grass for his dinner. 
"What the hell is this?" he screamed.

"Well," replied his wife, "If it's good enough for your girlfriend, then it's good enough for you!" (https://www.arrse.co.uk/community/threads/best-welsh-jokes.65286, 11 September 2017)

The language spoken in highlander jokes tends to be the dialect, naturally only occurring in what the highlanders say, because the narrator is seemingly an urban dweller. According to Tischner, the dialect is not only a different pronunciation of standard Polish words, but also a different way of thinking and describing the world (Sikora 2012: 138). The highlanders' speech is also likely to add a humorous value as it is filled with wit and a sense of humour. It also gives a sense of freedom and builds the common world between a speaker and a listener (cf. Gotówka 2016). 19 illustrates a play with words, but at the same time offers a certain abstract wisdom (the baca knows about the way things are), while 20 uses three colloquial idiomatic expressions situating three types of truth, the third one obviously being untruth. In 21 both the highlander and his wife use dialect (not quite visible in translation), while in 22 the reference is to habitual profanity that is typical of highlander speech.

19. Dwóch juhasów złapało jeża i spieraja się o nazwę tego zwierzęcia:

- To je śpilok - mówi pierwszy.

- Ni, to je iglok! - odpowiada drugi.

Prosza o werdykt starego bace, śpilok to czy iglok?

- To je ani śpilok, ani iglok. To je kolcok! - odpowiada baca.

(http://adonai.pl/humor/teksty/?id=32, 17 September 2017 )

[Two shepherds caught a hedgehog and they squabble how it is called:

"This is a spiky", says the first.

"No, it's a needlie", says the other.

They ask the old baca for the verdict, a spiky or a needlie?

"This is neither a spiky nor a needlie. This is a prickly!, answers baca.]

20. - Wojtek, wyście taki mondrala, wsytko prawie wiycie, to powiydzcie wiela jest prowd? Gazda ${ }^{7}$ na to:

- Jo znom jino trzy. Piyrso to świynto prowda, drugo tyż prowda, i trzecio gówno prowda.

(http://dowcipy.hahy.pl/k,26,baca,9.html, 17 September 2017)

["Wojtek, you are such a sage, you know almost all, tell me how many truths are there?" The highlander replies:

"I know three. The first one is the holy truth, the second the truth too, and the third one is bullshit."]

21. Idzie baca na dwór za potrzeba. Wraca calutki mokry. Gaździna się go pyta:

- Józwa, desc podo?

- Ni... ino halny wieje.

(http://www.dowcipy.jeja.pl/nowe,3,baca.html, 10 September 2017)

[Baca walks outside to relieve himself. He comes back in completely wet. His woman asks him:

"Jóźwa, is it rainin"?"

"No, just the foehn ${ }^{8}$ is blowing."]

22. Wychodzi baca przed chatupe, przeciaga się $i$ woła:

- Jaki piękny dzionek!

A echo z przyzwyczajenia:

- ...mać, mać, mać...!

(http://dowcipy.hahy.pl/pokaz,5377,A_echo_z_przyzwyczajenia.html, 17 September 2017)

[A baca walks out of his mountain hut, stretches and cries out: "What a beautiful morning!!

And the echo responds out of habit: "fuck you too... too... too"] 
The corresponding Welsh jokes emphasize the local linguistic peculiarity-namely, the extraordinary length of place names, in the context of total obscurity of Welsh for the speakers of English.

23. My wife asked me if I was having an affair with a woman from Llanfairpwllgwyngyllgogerychwyrndrobwyllllantysiliogogogoch.

I said: "How can you say such a thing?"

(http://www.walesonline.co.uk/lifestyle/fun-stuff/19-welsh-jokes-pretty-much-9562314, 11

October 2017)

24. On a beautiful summer's day, two English tourists were driving through Wales. At Llanfairpwllgwyngyllgogerychwyrndrobwyllllantysiliogogogoch they stopped for lunch and one of the tourists asked the waitress: "Before we order, I wonder if you could settle an argument for us. Can you pronounce where we are, very, very, very slowly?" The girl leaned over and said: "Burrr... gurrr... King."

(http://www.walesonline.co.uk/lifestyle/fun-stuff/19-welsh-jokes-pretty-much-9562314, 11

October 2017)

The use of dialect in case of the highlander jokes makes them similar also to the jokes about Scots. In both cases, the view of Davies holds that "the local speech is seen as having quality of crude masculinity", and the use of local speech patterns indirectly affirms and celebrates them. They make local people appear nostalgic, while others see them as picturesque (Davies 2001: 112). They evoke pride and affection. Local dialects used in jokes as a stylistic device enhance humour of the texts (Davies 2001: 120).

The figure of the highlander could be seen not only in the context of urban vs rural dichotomy, but also of the distinction between high context and low context, the broad, cultural divide introduced by Edward Hall (1976), who-briefly-argued that collective, close-knit, traditional, rural communities tend to communicate succinctly, orally, nonverbally, relying on the surrounding cultural context they share to complete the message, while more individualistic, modern, urban communities tend to communicate in more detail, verbally, and often in writing, because their joint share of their cultural context is much smaller. Thus the high-context highlander (baca) in jokes often speaks ambiguously or vaguely as he would to other highlanders. For example, in the following jokes, he - as a joke character-displays a sense of humour too, at the expense of the tourist, who asks him questions revealing his naiveté or lack of awareness or orientation:

25. Baco, a co trzeba zrobić, jak się w górach spotka głodnego niedźwiedzia?

- Nic nie musita robić, on już syćko za wos zrobi...

(http://www.dowcipy.jeja.pl/nowe,3,baca.html, 10 September 2017)

["Baca, what do you do when you meet a hungry bear in the mountains?"

"You ain't do nothing, he'll do all for you."]

26. Do bacy podchodza turyści:

- Baco, dojdziemy ta droga nad Morskie Oko?

- Jasne, prościutko tylko idźcie.

Gdy turyści odeszli baca mówi sam do siebie

- Przecie ziemia jest okragła.

[A baca is approached by tourists:

(http://www.dowcipy.jeja.pl/nowe,3,baca.html, 10 September 2017)

"Baca, shall we reach Morskie Oko lake when we walk this way?"

"Sure, just walk straight ahead."

When tourists have left, the baca says to himself:

"The earth is round, ain't it?"] 
27. Baco, jakie owce zjadaja mniej trawy: białe czy czarne?

- Czarne.

- A dlaczego?

- Bo czarnych jest mniej

["Baca, which sheep eat less grass: black or white ones?"

(HsG: 25)

"Black ones"

"And why?"

"Because there are fewer of them."]

Some of such jokes, e.g., 26, when a local dweller leads a visitor astray, find an equivalent in other folk cultures. Below is an example of a joke from Wales, where such behaviour has always been considered a source of local pride and a strategy to protect local inhabitants from intruders (cf. Davies 1978). In 28, the Welshmen gives the tourist a piece of non-advice, considering the question the latter asks a rather trivial one.

28. A tourist sauntered into a pub in Llandrindod Wells and said: "what's the quickest way to get to Brecon from here?

Rhodri the landlord answered: "Are you walking or going by car?"

The tourist answered: "By car, of course."

Rhodri said: "Well, that's the quickest way." (http://www.walesonline.co.uk/lifestyle/fun-stuff/19-welsh-jokes-pretty-much-9562314, 11

October 2017)

This condescending attitude could also be looked upon as an expression of the highlander pride, which was emphasized in the analysis of the above-mentioned Montenegro jokes (Koncewicz-Dziduch 2017: 76-77):

29. How does a Montenegrin grade adjectives? Nice, nicer, me.

30. How do Montenegrin sparrows greet each other? How are you, falcon!

\section{Logical mechanisms in highlander jokes}

In the pre-final section it is time to carry out short analysis of highlander jokes in terms of their peculiar logic, referred in humour scholarship literature as "local logic" (Ziv 1984: 90). Attardo (2001: 27) developed this idea and listed the following logical mechanisms:

role-reversals, role exchanges, potency mappings, vacuous reversal, juxtaposition, chiasmus, garden-path, figure-ground reversal, faulty reasoning, almost situations, analogy, selfundermining, inferring consequences, reasoning from false premises, missing link, coincidence, parallelism, implicit parallelism, proportion, ignoring the obvious, false analogy, exaggeration, field restriction, cratylism, meta-humour, vicious circle, referential ambiguity.

Highlander jokes bear a comparison to Jewish jokes in the importance of their commonsensical, but at the same time surprising logic (see also Oring 2016 on logic in Jewish jokes, where he argued that in reality they use no qualitatively distinct logic). In the four examples below we can see three jokes where the highlander's perception of places (31), events (32) or activities (33) differs from that of a tourist. Mount Giewont from joke 31 is considered the symbol of Zakopane (the capital of the Polish Tatras) with a huge metal cross on top, and so every tourist wants to see it and even climb it. ${ }^{9}$ Still sometimes the foggy mountain weather makes the mountain invisible, which tourists, unaware of things in the mountains, find 
difficult to understand, hence the answers of the highlander in 31-helpful and unhelpful at the same time. The logical mechanism postulated here is likely be that of figure-ground reversal (the unimportant foreground being visible, the important background being invisible, but still pointed at).

31.- Baco, czy pokażecie nam Giewont? - pytaja turyści.

- Jo. Widzita tom pirwszom górke?

- Tak.

- To nie je Giewont. A widzita tom drugom górke?

- Tak.

- To tyz nie je Giewont. A widzita tom trzeciom górke?

- Nie.

- To je Giewont.

(http://www.dowcipy.jeja.pl/nowe,3,baca.html, 10 September 2017)

[“Baca, will you show us Mount Giewont?", tourists ask a baca.

"Yeah. D'you see that first hillock?

"Yes"

"That isn't Giewont. And d'you see that second hillock?"

"Yes."

"That isn't Giewont either. And d'you see that third hillock?

"No."

"That's Giewont."]

32 is interesting as it calls on the high context communication referred to earlier in this article. The baca says less than he could have said in a regular interrogation procedure, but we are surprised how much he means by saying so little.

32. Baca byt świadkiem wypadku samochodowego: Poldek walnąt w drzewo. Przestuchuje go gliniarz:

- Baco jak to było?

Na to baca:

- Panocku widzicie to drzewo?

- Widzę.

- A oni nie widzieli...

(http://www.dowcipy.jeja.pl/nowe,3,baca.html, 10 September 2017)

[A baca witnessed a car accident. Poldek hit a tree. A cop is interrogating him.

"Baca, how did that happen?"

The baca says"

"Mister, do you see that tree?"

"I do."

"And they didn't."]

The logical mechanism is that of false analogy, as naturally the vantage point of the policemen while talking to the highlander would be different than that of the participants in the crash. Moreover, the testimony is not good enough as the policemen would want to know as many details as he could and is not normally looking for such synthetic descriptions. Nonetheless, the highlander's ability to synthesize is admirable - the gift to see through details and get at the essence of the problem, however trivial it would be. The highlander is the philosopher again, as Tischner would want him to be: the philosopher of perception. A quotation from Władek the Plato, who taught local girls about man's love, illustrates this philosophical, cut-through-the-problem approach. He said to them: 
"...true beauty sits in the soul, and does not lie on the surface of the body. And you seek which girl has a beautiful soul. A noble one. A charming one. And as pure as water in the spring. And you sit next to that one. And you bear beautiful thoughts next to her. And you make little poems. And you sing. Then you are under a spell—of that soul." 10

(Tischner 2003a: 87).

This philosophical approach seems to corroborate Oring's point about the essence of jokes (see this issue) when he claims: "I have always thought of jokes more as a philosophy than therapy - as commentary rather than catharsis" (Oring 2017: 7).

The third example in the series (33) illustrates the ignoring the obvious mechanism, where the highlander does not recognize the pushups as a sports activity and makes a surprising, but not unlikely connection (in the spirit of local logic). The mechanism of ignoring the obvious clearly depends on the perspective of the observer, and here the vantage point of the narrator is that of the urban dweller again. Of course, it cannot be denied that this observation reveals the prevalence of the sexual perspective in the highlander's mind and the above-mentioned "technical" aspect of it again.

33. Idzie baca przez połoniny $i$ widzi jak turysta robi pompki dla zdrowia. Stanąt $i$ kiwa głowa $z$ podziwem.

- Różne ja wiatry widziatem, ale żeby babę spod chtopa wywiato...?

(http://www.dowcipy.jeja.pl/top,3,baca,8.html, 17 September 2017)

[The baca walks across high meadows and spots the tourist doing pushups-to keep fit. He stops and nods his head in admiration.

"I have seen different winds, but for a woman to be blown away from under a man?]

The last joke example illustrates an interesting communication pattern again, probably best described as garden path (deliberate miscommunication, leading the listener astray) as the question is asked of a baca (probably by his fellow highlander, but this is not clear) and he responds to its conventional, well-meant communicative value (offer to sell wood), while what is meant is whether he needs the wood he already has (offer to take away the unnecessary wood) (see Arons 2012, where in the chapter on playing with pragmatics, she discusses speech acts jokes). The English translation loses the referential ambiguity of the phrase as the Polish noun drewno (as other Polish nouns) is unspecified as to its definiteness and could be interpreted as either definite of indefinite depending on the context.

34. Baca styszy krzyki z podwórka:

- Czego tam?

- Bacoooo! Potrzebujecie drewna?

- Nieeee!

Rano baca budzi się, wychodzi na podwórko, patrzy:

- O kur..! Gdzie moje drewno?!

(http://www.bzdura.pl/kawaly/kawal-4-8350.html, 17 September 2017)

[Baca can hear the shouting from the yard.

"What d'you want?"

"Bacaaaa! Do you need (the) wood?

"Nooo!

In the morning the baca wakes up, walks into the yard, and looks" "Fuck! Where's my wood?"]

In the table below the logical mechanisms have been identified in all the 25 highlander jokes used as examples in the article. 
Table 1. Logical mechanisms in highlander jokes (the jokes can be identified by the key phrase and number)

\begin{tabular}{|l|l|l|l|l|l|l|l|}
\hline $\begin{array}{l}\text { False } \\
\text { analogy } \\
\mathbf{( 3 )}\end{array}$ & $\begin{array}{l}\text { Reasoning } \\
\text { from false } \\
\text { premises } \\
\mathbf{( 2 )}\end{array}$ & $\begin{array}{l}\text { Faulty } \\
\text { reasoning } \\
\mathbf{( 3 )}\end{array}$ & $\begin{array}{l}\text { Ignoring } \\
\text { the } \\
\text { obvious } \\
\mathbf{( 4 )}\end{array}$ & $\begin{array}{l}\text { Garden } \\
\text { path (4) }\end{array}$ & $\begin{array}{l}\text { Role } \\
\text { reversal } \\
\mathbf{( 4 )}\end{array}$ & $\begin{array}{l}\text { Figure } \\
\text { and } \\
\text { ground } \\
\mathbf{( 4 )}\end{array}$ & $\begin{array}{l}\text { Juxtaposition } \\
\text { (1) }\end{array}$ \\
\hline $\begin{array}{l}\text { two } \\
\text { little } \\
\text { pigeons } \\
(10)\end{array}$ & $\begin{array}{l}\text { the } \text { baca } \\
\text { moaning } \\
(3)\end{array}$ & $\begin{array}{l}\text { earthworm } \\
(2)\end{array}$ & $\begin{array}{l}\text { police } \\
(1)\end{array}$ & $\begin{array}{l}\text { anything } \\
\text { in your } \\
\text { defence? } \\
(9)\end{array}$ & $\begin{array}{l}\text { I will } \\
\text { stink (6) }\end{array}$ & $\begin{array}{l}\text { I have no } \\
\text { planks } \\
(8)\end{array}$ & prickly (19) \\
\hline $\begin{array}{l}\text { earth is } \\
\text { round } \\
(26)\end{array}$ & $\begin{array}{l}\text { I just sit } \\
(5)\end{array}$ & $\begin{array}{l}\text { a chap got } \\
\text { sucked in } \\
(12)\end{array}$ & $\begin{array}{l}\text { I'll not } \\
\text { look at } \\
\text { alcohol } \\
(7)\end{array}$ & $\begin{array}{l}\text { bullshit } \\
(20)\end{array}$ & $\begin{array}{l}\text { I have } \\
\text { such a } \\
\text { hag (13) }\end{array}$ & $\begin{array}{l}\text { Just a few } \\
\text { trees (11) }\end{array}$ & \\
\hline $\begin{array}{l}\text { And } \\
\text { they } \\
\text { didn't } \\
(32)\end{array}$ & & $\begin{array}{l}\text { black sheep } \\
(27)\end{array}$ & $\begin{array}{l}\text { the foehn } \\
\text { is } \\
\text { blowing } \\
(21)\end{array}$ & $\begin{array}{l}\text { Fuck } \\
\text { you too } \\
(22)\end{array}$ & $\begin{array}{l}\text { the fur } \\
\text { coat } \\
(14)\end{array}$ & $\begin{array}{l}\text { the pot } \\
\text { was } \\
\text { expensive } \\
(14)\end{array}$ & \\
\hline
\end{tabular}

What is striking in the above table is that the selected highlander jokes tend to have one of the reasoning (false analogy, reasoning from false premises, faulty reasoning, ignoring the obvious, garden path) or reversal mechanisms (role reversal, figure and ground), and the "simpler" mechanisms such as juxtaposition or exaggeration are missing from the table. This points us towards the cleverness of the jokes as well as the unsimplistic figure of the highlander as he is portrayed in the jokes by the Polish narrator or joke teller.

\section{Conclusions-mind over matter?}

To conclude, let us return to the issue of cleverness or stupidity of the highlander. In his discussion of the prevalence of mind over matter, Davies (2011a: 21) stresses that "those whose occupations or very being are most strongly associated with material things are likely to become the butt of stupidity jokes". The highlanders' occupation is traditionally sheep grazing, forestry, berry and mushroom picking or sometimes construction, thus they would qualify as associated with material things, although Davies claims the heterogenous nature of the material. It is in his view opposed to the intellectual, although

[b]ehind the way jokes fit the mind-over-matter model may lie the prestige given particularly in the past to those who dealt with the pure world of the spiritual, the elevated, and the abstract over 
the useful and practical, but today the jokes are best seen as an aspect of a modern world in which change is driven by knowledge and commerce. (Davies 2011a: 269)

Even in this short quote we can see how the problem of the spiritual and the abstract somewhat complicates the fine model and requires a gloss - the Polish highlander's thinking as depicted in jokes is robust, earthy, body-driven, and yet it also displays a great deal of abstract thinking as well as a kind of concrete-minded spirituality:

35. Góral z Zakopanego pojechat załatwić sprawe w ważnym warszawskim urzędzie. Ponieważ sekretarka nie chciała go wpuścić do gabinetu, wykrzyknąt: - Pani nie wie, co ja za jeden! Jestem szwagrem Pana Boga! Po tych stowach sekretarka wpuściła go do ministra, a góral szybko załatwit swoja sprawę. Na końcu minister

pyta: - Baco! Powiedzcie, jak to możliwe, że jesteście szwagrem Pana Boga? - Nooo... Byty dwie siostry. Jedna, kiedy pomarta, wzią Pan Bóg, a druga - ja.

(http://www.zsnbozejewice.pl/Traper/GAZETA\%20PTTK/12.pdf)

[A highlander from Zakopane goes to Warsaw to deal with an important business in an office there. Since the secretary does not want to let him in to see the minister, he shouts: "You don't who I am! I am God's son-in-law!" After that the secretary quickly let him, and the highlander quickly obtained what he had come for. In the end the minister asks him: "Baca, do tell me, how is that possible you are God's son-in-law?"

"Well... there were two sisters. One of them when she died was taken by God, and the other by me.]

This is the kind of creative highlander that Tischner had in mind when he wrote that Greeks were actually born in the Highlands. In this case mind seems to prevail over matter, although in other cases matter wins over. The highlander jokes might have the same global background of urban vs rural, centre vs periphery oppositions as the jokes from Wales or Montenegro, but still their local, culture-specific nature affects their interpretation for the local audiences, the interpretation much influenced by such philosophers as Tischner, and many poets, writers, playwrights, composers, and other artists before him who sang praises of the Tatra Highlands as the place of culture and tradition. Thus the serious cultural tradition seems to have overlapped with that of the jokes and suppressed those features of the figure of baca which made him a primitive brute.

To conclude we could briefly say that highlander jokes retain their popularity among Poles, and their sometimes odd, but common-sensical logic have now become stereotypical. The image of a highlander, a simple but sophisticated rural philosopher, brings enjoyment to the young and old alike. At the same time it illustrates the principle of "mind over matter" expertly argued by Davies (2011a: 67): "It is only jokes about the stupid that fit into reasonably simple formulae...All stupid people are stupid in the same way, whereas clever people are clever in many ways."

As a matter of fact, the Polish highlander is both stupid and clever, he is both central and peripheral, he is both mind and matter. Here another clear affinity comes to mind - the Good Soldier Švejk, the comic character by Jaroslav Hašek much beloved by Davies (e.g., Davies 2000), who was also such a character-seemingly stupid, he showed surprising clarity of mind and logic, even though he kept reiterating to everyone, especially all his superiors, that he was stupid from birth, thus representing the type of character that folklore researchers have dubbed a wise fool (alternatively, an artificial fool, cf. Weitz 2014, or jester cf. Otto 2001). The Polish highlander thus perhaps resembles Švejk slightly more than his fellow highlanders from Wales or Montenegro - he is, inconsistently, but still-a wise fool of southern Poland. The comments that Davies wrote about Švejk could apply to baca as well: after all he is free inside, not constrained by a sense of the crushing legitimacy of the social order (Davies 2000: 448), which he overcomes by passive sabotage. The nature of jokes 
thrives on ambiguity and incongruity, often leaving us with the question "Who was the real butt of the joke?" (Davies 2000a: 453). In the case of highlander jokes the question would simply be: baca or ceper?

\section{Notes}

${ }^{1}$ Cf. Stanisław Wyspiański's famous play The Wedding from 1901, which focuses on the rural wedding ceremony of a man from the town of Kraków and a girl from the village and gives rise to national mythology. Among other intellectuals the writers and poets Kazimierz Przerwa-Tetmajer and Jan Kasprowicz, the composers Mieczysław Karłowicz and Karol Szymanowski, architect Stanisław Witkiewicz and his son, the writer and playwright Stanisław Ignacy Witkiewicz come to mind as the most prominent.

${ }^{2}$ Christie Davies once almost met Tischner, who was a keynote speaker at the religion conference held at the Jagiellonian University in Kraków in the mid-1990s that Davies was attending too. Tischner, however, came quite late to his own lecture and Davies decided that a renowned Catholic philosopher he might be, but one should not be so shamelessly late, and left the conference indignantly.

${ }^{3}$ Although contrary to Scots, Polish highlanders were all Roman Catholics.

${ }^{4}$ The traditional highlander washed his body on Saturday night in preparation for the Sunday mass (for which he dressed his best), which was shocking for Americans of the time, as they had grown in the soap and detergent culture of cleanliness - see Davies (2002: 151173) where he discusses the rise of Polack jokes.

${ }^{5}$ A pun - the original dialectal police (standard Polish: policze) translates as "I will count".

${ }^{6}$ The corpus of jokes gathered here cannot be considered exhaustive, but still an attempt was made to list as many diverse types of jokes as possible that would best illustrate the figure of the highlander. It should be added that this joke cycle is no longer developing, thus most of the joke variants that can be now encountered reiterate known patterns.

${ }^{7} \mathrm{Gazda}$ is a form of address used in the highlands to refer to a homestead owner. It is also used by urban folk or tourists to refer to any highlander they meet.

${ }^{8}$ The halny (foehn) wind is a regular phenomenon in the Tatras and Tatra foothills. It is a strong wind blowing sometimes ceaselessly for a few days, and bringing the change of the weather.

${ }^{9}$ During the summer hundreds of tourists line up and wait for hours along the tourist trail winding up Mt Giewont, just in order to be able to touch the cross on Mt Giewont. The crowds are often surprised by bad weather and find it difficult to climb down, particularly that some tourists wear inappropriate shoes, notably high heels, and are then rescued by the mountain rescue service.

${ }^{10}$ The speech was interrupted by one of the girls who asked: "Will such one marry?", whereupon Władek the Plato said: Eeee! And the girl felt very angry and said: "Hey, such can only watch". And this is how Władek’s teaching of the girls ended (cf. Tischner 2003a: 87)

\section{Appendix}

Sources of jokes

Kałamacki, S. (ed.) (nd) Super humor spod Giewontu (SHsG). Zakopane: Stanmar 
Kałamacki, S. \& Nieciągły, Z. (eds.) (nd) Humor spod Giewontu (HsG). Warszawa-Zakopane: Perspektywy Press.

Pinkwart, M., Pytlik, Z., 2002, Góralskie jaja. Mała antologia humoru góralskiego, Zakopane. http://www.dowcipy.jeja.pl, 12 September 2017

http://www.bzdura.pl, 12 September 2017

http://dowcipy.hahy.pl, 12 September 2017

http://adonai.pl/humor/teksty/?id=32, 12 September 2017

http://dowcipy999.pl/categories/dowcipy-o-bacy, 12 September 2017

http://irek-wojciech.republika.pl/humor/temat/obacy1.htm, 12 September 2017

https://pl.wikipedia.org/wiki/Baca, 12 September 2017

http://www.zsnbozejewice.pl, 4 December 2017

http://www.walesonline.co.uk/lifestyle/fun-stuff/19-welsh-jokes-pretty-much-9562314,

September 2017

https://www.arrse.co.uk/community/threads/best-welsh-jokes.65286, 11 September 2017

http://www.celticcountries.com/humour/28-jokes-about-the-welsh, 11 September 2017

\section{References}

Arons, D. (2012). Jokes and the Linguistic Mind. New York: Routledge.

Attardo, S. (2001). Humorous Texts. Berlin, New York: Mouton de Gruyter.

Attardo, S. \& Raskin, V. (1991). 'Script theory revis(it)ed: Joke similarity and joke representation model', Humor: International Journal of Humor Research 4 (3/4), pp. 347-411.

Davies, C. (1978). Welsh Jokes. Cardiff: John Jones.

Davies, C. (2000). 'The savage style of Jaroslav Hašek: The Good Soldier Švejk as a politically incorrect comic masterpiece', Stylistyka 9, pp. 301-315.

Davies, C. (2000a). 'Mr Polly and the Good Soldier Švejk; a contrast in style and social context', in Gajda, S. \& Brzozowska, D. (eds.), Świat humoru, Opole: Wydawnictwo Uniwersytetu Opolskiego, pp. 447-459.

Davies, C. (2001). 'The humorous use of the contrast between standard educated English and local dialect in Scottish jokes', Stylistyka 10, pp.111-124.

Davies, C. (2002). The Mirth of Nations, New Brunswick NJ, Transaction.

Davies, C. (2004). 'Victor Raskin on jokes', Humor: International Journal of Humor Research 17 (4), pp. 373-380.

Davies, C. (2011a). Jokes and Targets. Bloomington, IN: Indiana University Press.

Davies, C. (2011b). 'Logical mechanisms: A critique', Humor: International Journal of Humor Research 24 (2), pp. 159-165.

Davies, C. (2016). 'How jokes change and maybe changed: Simplifying, transforming and revealing', Pótrocznik Językoznawczy Tertium. Tertium Linguistic Journal 1 (1\&2), www.journal.tertium.edu.pl.

Gotówka, A. (2016). 'The meaning and perception of soul in the culture of the Podhale region', Adeptus Pismo Humanistów 7, pp. 1-10.

Hall, E. (1976). Beyond Culture. New York: Anchor Books.

Koncewicz-Dziduch, E. (2017). 'Sociocultural characteristics of Montenegrins - the negative message in positive jokes', European Journal of Humour Research 5(2), pp.71-79.

Oring, E. (2016). Joking Asides. The Theory, Analysis and Aesthetics of Humor. Logan: Utah University Press.

Oring, E. (2017). 'The consolations of humor', European Journal of Humour Research 5(4), pp. 1-11. 
Otto, B.K. (2001). Fools are Everywhere: The Court Jester Around the World. Chicago: University of Chicago Press.

Rak, M. (2015). Kulturemy podhalańskie, Biblioteka LingVariów 19. Kraków: Księgarnia Akademicka.

Sikora, J. (2012). 'Kazania góralskie', in Sikora, J. (ed.), Twórczość kaznodziejska ks. Józefa Tischnera, Warszawa: Wydawnictwo Uniwersytetu Kardynała Stefana Wyszyńskiego, pp. $134-151$.

Tischner, J. (2003a). Historia filozofii po góralsku. Kraków: Znak.

Tischner, J. (2003b). Spotkanie: Z ks. Józefem Tischnerem rozmawia Anna Karoń-Ostrowska. Kraków: Znak.

Weitz, E. (2014). 'Fools', in Attardo, S. (ed.), Encyclopedia of Humor Studies, vol. 1. Los Angeles: Sage, pp. 243-245.

Wyspiański, S. (1998 [1901]). The Wedding. Transl. by Clark, N. Oberon Books: London.

Ziv, A. (1984). Personality and Sense of Humor. New York: Springer. 